Acta Universitatis Wratislaviensis No 3920

Anglica Wratislaviensia LVII, Wrocław 2019

DOI: $10.19195 / 0301-7966.57 .13$

\title{
Maciej Kaczmarczyk
}

ORCID: 0000-0002-3658-2060

University of Wrocław

makaczm1@onet.pl

\section{An Analysis of Junior High School Students' Skill in Creating Written Compositions: A Research Report}

\begin{abstract}
This article is a report based on a qualitative study on the skills needed for junior high school students to produce written compositions in the context of creating a short message. This kind of research has been made necessary by the implementation of an obligatory exam for junior high school graduates, including a writing part in which there are some requirements to be met in order to obtain a positive grade. Although the recent educational reforms mean that junior high schools will no longer exist, this research is useful in the diagnosis of the writing skills of Polish teenagers that will be going into high school. The results have shown that the students had no major problems with such requirements as text organization, punctuation rules and with keeping to the word limit for a given written composition. On the other hand, however, the students showed the need for improvement in formal aspects of the written English language such as grammar, vocabulary (accuracy and spelling) and transition signals. Additionally, the meeting of requirements (mentioning and developing three elements) should be practiced more. For the purpose of the study, an analysis sheet has been implemented but no hypotheses have been put forth. The research group included 33 written compositions.
\end{abstract}

Keywords: junior high school, written compositions, grammar, vocabulary, spelling, exam, transition signals, punctuation

\section{Introduction}

\subsection{The characteristics of writing}

Itself a skill, writing has its own characteristics such as permanence, distance, orthography, complexity, register, organization and choice of vocabulary. The first feature means that the piece of writing will remain available for reading for a period of time. Distance covers the phenomenon of the gap between the writer and the reader. A speech act has immediate receivers, while a written piece may 
have to wait for some time before being read (for example a postcard or a letter being sent to the receiver). The text is managed by orthographic features such as capital letters, commas, exclamation marks and dashes. Additionally, the writing is organized into paragraphs. In terms of complexity, writing is more complex than speech. The clauses are longer and cohesion and coherence are of importance. As far as register and vocabulary are concerned, the piece of writing can be produced in a formal and informal way. The vocabulary can be carefully chosen because the writer has more time to choose and use the words than a speaker, who often articulates speech faster than a written message (Council of Europe 117; Harmer 29, 45-46; Ur 152-53; Weigle 15-16).

According to Brown, writing consists of micro-skills and macro-skills (220-21). The micro-skills focus on orthography, writing rate, word bank, word order, appropriate grammar patterns, cohesive devices and expression of meanings in different forms. The macro-skills implement rhetoric and conventions, communicative functions, the linking of ideas, meaning discrimination, writing strategies and cultural references. Writing can also be of different types, i.e. imitative, controlled, responsive or extensive (Brown 220-21).

Written discourse may be divided into two types: dominant intention and cognitive processing. As far as dominant intention is concerned, the text may teach, inform, convince or persuade, convey emotion, entertain or delight and allow its author to keep in touch with the other person. Cognitive processing involves three types of processing. Type I implements the reproduction of information, i.e. dictation or form-filling (the least demanding of all types). Type II incorporates the organization and arrangement of information, i.e. laboratory report. Type III includes the invention of information, i.e. knowledge transformation (the most demanding) (Weigle 10).

As far as planning is concerned, writing may be viewed as product- and process-focused. Product writing involves producing a text which is written with its assessment in mind. The writer has no time to consult the piece of writing with the teacher. The process is of minor importance here. On the other hand, process-writing is focused on both the product and the process, although the second feature is more important. In the process approach to writing, the writer has some time to edit and polish the text. Also drafting and redrafting are possible here. The final version is not produced immediately (Harmer 325-27; Ur 152).

Nevertheless, cohesion and coherence and the conveyed messages are assessed independently from the writing approach that may have been applied (Harmer 29; Weigle 14-15; CKE, Informator 102-103). These features will be discussed in the latter part of the article.

All these aspects presented above were necessary in order to show the characteristics of the skill, because all of these components are assessed in the obligatory examination. Let us look at interlanguage in writing to see its nature. 


\subsection{Interlanguage in writing}

Being a skill, writing is influenced by constant change. Researchers have observed that the phenomenon of so-called "interlanguage" relates to the skill of writing. The phenomenon itself is also referred to as: intermediate states, an approximative system, learner language, non-native speaker knowledge, learner varieties or learners' own language systems. One of the most questionable synonyms for interlanguage is a third language system (Brown 243; Dakowska 86; Saville-Troike 40-41, 58). To relate to the synonyms of the phenomenon, let us focus on the definition of interlanguage, which has multiple interpretations, although there are some features that can be called unchangeable. Interlanguage is, then, a gap between the language the learner aims to achieve and the language which is produced by the learner. That is why it is seen as a distorted variety of the target language (Brown 243; Pawlak 120). For some researchers, interlanguage, to some extent, is seen as independent from both the first and the target language (Saville-Troike 43).

As interlanguage is a system which changes constantly, it is seen as a system which aims at being native-like. It consists of four stages: pre-systematic, emergent, systematic and post-systematic (Brown 244). The pre-systematic stage includes random errors. This is because the learner is not yet familiar enough with the target language system (Brown 244). The emergent stage can be problematic for several reasons. The first is backsliding, which is a regression to the state of knowledge from the previous stage. Although backsliding exists, the learner is aware of the correct rule. Backsliding is connected with the phenomenon of U-shaped learning, which is characterized by the sequence of first producing the correct form, later going back to the incorrect one and then uttering the correct form again. Additionally, although the interlocutors point out the error to the learners, they cannot correct themselves. What is typical for this stage is topic and structure avoidance. This means that the student does not use some structures or does not talk about some topics due to lack of confidence. As for the positive features of the emergent stage, the learner makes some progress and the utterances which are produced are increasingly more understandable than those produced in the pre-systematic stage (Brown 245). At the third stage, the systematic one, more and more consistency of the learner's utterances can be observed. What is good about this stage is that if the interlocutor points the error out to the learner, self-correction is possible (Brown 245). In the last stage, the post-systematic one, there are no problems with self-correction, fluency and meanings. Errors are rare here. The problem at this stage, however, can be fossilization, which is seen as regression in the development of the target language before reaching the native-like form (Brown 246; Saville-Troike 41-42). In reference to the skill of writing, the above-mentioned phenomena can also occur during the process of developing native-like writing.

This section has presented changes in the writing skill and possible problems throughout the process of learning it. Let us now focus on the history of the treatment writing as a language skill. 
1.3. The history of the treatment of writing in different teaching methods

As far as the history of writing is concerned, many approaches have been attempted throughout the decades. The first method to discuss the writing skill is the Grammar Translation Method (or the Classical Method or the Prussian Method) dating to the 19th century (Dakowska 17). Here writing was used for translating from the mother tongue into the target language or the other way round. However, its aim was the analysis of the text, but not communication (Dakowska 19-20; Brown 15-16). On the other hand, the two following methods date back to the 20th century. The Direct Method (the Natural Method) and the Reading Method saw the skill of writing as of minor importance and they both were not interested in the production of the written language (Dakowska 23-27). The following method, which is the Audiolingual Method (the Oral Method, ALM, the Army Method, the Situational Method), treated written language as being subordinate to the speaking skill but not as important as speaking. Moreover, the method focused on controlled and guided product writing. The technique which was of interest was rewriting. The example shows the length of texts was one paragraph (Brown 16-17; Dakowska 39-40, 248). Following on from Transformational Generative Grammar (TGG), the Cognitive Approach (or Cognitive Code Learning, the Cognitive Method) originated. As far as the writing skill was concerned in this method, the techniques which were used were opinion papers, narratives, for and against formats or argumentative writing. On the other hand, however, controlled writing was also important (Dakowska 57-62, 248). The later method (and not an approach) which focused on writing was Communicative Language Teaching (CLT). The main aim there was to develop communicative competence by promoting pair and group work. The method focused more on speaking, but all the language skills had to be developed (Dakowska 103-105). In terms of the writing techniques used in CLT, there were personal letters, opinion papers, application letters, leaflets, compositions, advertisements, instructions and letters of complaint (Dakowska 108).

Writing was seen differently in different teaching methods. Nowadays it is again important because it is a part of the exam. After this presentation of the history of treatment of writing, let us look at the context of the research.

\section{The context of the research}

Writing in English is the most demanding skill of all because English spelling does not correspond to pronunciation. Today students have the access to applications where they text or type messages like e-mails or short messages using software for communication, hence they seem not to practice the skill of writing.

As has been mentioned earlier, the more contemporary view on writing as a skill and the components of a writing task will be examined here. At the time of this research, the importance of the writing skill in junior high schools was reflected in students being required to take an exam at the end of this stage of schooling (CKE, 
Informator 102-103). As far as the requirements for writing as a skill are concerned, the Common European Framework of Reference implies that the student who is at junior high school should achieve the A2 level of proficiency. The document suggests that what is demanded at this level is the skill of producing uncomplicated "personal letters" and notes which are "of immediate need" (Council of Europe 83). According to the core curriculum, junior high school students who are continuants of the language course, are at the III.1 stage (MEN 22). It means that they are obliged to be skilful in producing short, simple and understandable pieces of writing. Among all, one form is mentioned, which is the short private letter (MEN 35). Additionally, another requirement for the junior high school student is the number of words for a written composition, which is from 50 to 100 words (CKE, Informator 102). As far as the sources are concerned, what has been found were studies focused on a different skill than writing, i. e. speaking. Moreover, exam reports have been found. They were matura exam reports and junior high school exam reports, but they could not serve as a sufficient source of information about the skill of writing. Analyzing the literature provided no satisfactory or exhaustive data and that is why there was a need to conduct research on the writing skill (Lipińska 139-144; Zając 65-146; CKE, Osiagnięcia uczniów kończacych gimnazjum w roku 2015 122, 133-138; CKE, Sprawozdanie z egzaminu maturalnego 2015 7-11, 20-26; CKE, Osiagnięcia uczniów kończacych gimnazjum w roku 2016 124, 135-140; CKE, Sprawozdanie z egzaminu maturalnego 2016 7-12, 16-17, 23-28). The graduation exam at the advanced level is divided into eight tasks. The total number of points for the test is 40 and the time allocated for it is 60 minutes. The listening part consists of two exercises where students face recognition and matching tasks. The reading part contains three exercises. The part with language aspects is made up of two exercises. The writing part includes one exercise which is worth 10 points, hence $25 \%$ of the total points. In this part, students have to mention three aspects and develop them. What is assessed are content (maximum 4 points), coherence (up to 2 points), range of language (up to 2 points) and the accuracy of language (maximum 2 points). The students should know the basic range of language to communicate on the subjects of human beings, family life and food. They should also create e-mails where they describe people and activities, give and justify their opinions, show other people's opinions and use formal or informal register depending on the situation.

\section{Research description}

The aim of the research was to examine the length, the quality and the correctness of the written compositions of junior high school students. The method which seems to be suitable for this kind of an analysis is the qualitative one and it has been incorporated by analyzing all of the written compositions (Kaczmarczyk 3, 42-44). The rationale for the qualitative method for this kind of research is that the 
research group was not big enough to use statistics and the interpretation of results seems to be less restricted but also more thorough than in the quantitative method.

\subsection{The research instrument}

For this purpose, a single analysis sheet has been chosen for the analysis of the written compositions. The sheet focuses on criteria such as number of words, number of sentences, number of inadequate vocabulary items, mistakes in spelling, mistakes in grammar, number of transition signals, number of requirements met, mistakes in punctuation and mistakes in organization of text. Additionally, the sheet has been divided into 33 columns, each of them for one written composition. The researcher has analyzed and noted down the frequency of occurrence of a given phenomenon, for example, how many mistakes in grammar appeared in a given written composition. An example of the analysis sheet can be found in the Appendix (Kaczmarczyk 42-44).

\subsection{The research group}

In terms of the research group, 33 written compositions produced by third-grade junior high school students have been collected. The students wrote the compositions (personal letters) on two topics (on a sports camp and on buying a present) to practice before the exam (Kaczmarczyk 44). The requirements for the writing task were described above (point 2).

\subsection{The research questions}

Three major research questions and six additional questions have been incorporated. The rationale for the questions is that the junior high school students have to take the end-of-school exam and the writing task is a part of it, so research into their skill in writing should be done in order to find out the strengths and weaknesses of the skill and find areas of necessary improvement. The questions are shown below (Kaczmarczyk 3, 42-43).

Q1: To what extent do the students know the rules of creating written compositions at the A2 level of proficiency in terms of text organization requirements and the requirements coming from the Informator o egzaminie gimnazjalnym od roku szkolnego 2011/2012 for accomplishing the written composition task?

Q1.1: To what extent are the students familiar with the application of the rules of text organization?

Q1.2: How many students have problems with understanding the requirements of the written composition?

Q2: To what extent do the students know how to write a composition at junior high school in terms of the formal aspects of language? 
Q2.1: To what extent are the students familiar with the application of the rules of punctuation?

Q2.2: To what extent are the students familiar with the application of the rules of grammar?

Q2.3: To what extent do the students use the transition signals (however, first, etc.)?

Q2.4: What is the choice of vocabulary in written composition?

Q2.5: To what extent are the students familiar with the application of the spelling rules?

Q3: What is the average length of the written composition in third-grade junior high school students?

\section{The results}

Firstly, all the questions asked for the purpose of the research have been answered. The answers are shown in the table 1.

Table 1: Answers to the research questions. Based on Kaczmarczyk (44-65)

\begin{tabular}{|l|}
\hline Answer to Q1 (see answers to Q1.1 and Q1.2) \\
\hline Answer to Q1.1: $51.5 \%$ of the written compositions were well-organized. \\
\hline Answer to Q1.2: 21.21\% of the written compositions where all requirements were met. \\
\hline Answer to Q2 (see answers to Q2.1, Q2.2, Q2.3, Q2.4 and Q2.5) \\
\hline $\begin{array}{l}\text { Answer to Q2.1: Punctuation mistakes constituted } 8.7 \% \text { of the total number of mistakes. 30.3\% } \\
\text { of the written compositions were without any punctuation mistakes. }\end{array}$ \\
\hline $\begin{array}{l}\text { Answer to Q2.2: Grammar mistakes constitute } 37.6 \% \text { of the total number of mistakes. > } 1 \text { gram- } \\
\text { mar mistake per 1 sentence. }\end{array}$ \\
\hline Answer to Q2.3: 1 transition signal only (3.03\%) of the total number of vocabulary items. \\
\hline Answer to Q2.4: 32.27\% of inadequate vocabulary in relation to all words. \\
\hline Answer to Q2.5: Spelling mistakes constitute $16.6 \%$ of the total number of mistakes. \\
\hline $\begin{array}{l}\text { Answer to Q3: 78.5-it is a tolerable number of words for one written composition. Only } 5 \text { com- } \\
\text { positions had an inappropriate number of words (15.15\%). }\end{array}$
\end{tabular}

As a commentary to the table, it is necessary to notice that the total number of words was 2,591 and the total number of mistakes of any kind was 471 . In addition, the total number of sentences was 244 and the ratio between the number of words and number of sentences will be shown later in the article (Kaczmarczyk 64-65). To explain the answer to question Q1.1, what has been observed is that the largest number of mistakes made in the organization of the text is 3 (observed in 
1 composition) and the lowest is 1 (seen 10 times). Relating the number of this type of mistakes (23) to their overall number (471), the percentage of text organization mistakes is approximately $4.88 \%$ (Kaczmarczyk 45-46). In terms of additional information for Q1.2, it is worth mentioning that the majority of the written compositions $(42.42 \%)$ contained 5 requirements which had been met. The largest number of these is 6 and 2 is the lowest (Kaczmarczyk 55-56).

As a commentary to Q2.1, it is good to know that there were 10 written compositions without any punctuation mistakes. The highest number of punctuation mistakes is 5 , but there were also cases of no mistakes of this kind. Additionally, the ratio of 5.95 between the number of sentences and the mistakes in punctuation shows that merely every 6th sentence contained one mistake of such a kind (Kaczmarczyk 46-47).

In terms of the grammar question (Q2.2), it has been observed, based on the ratio between the number of sentences and the number of grammar mistakes (1.38), that there would be almost 2 mistakes in grammar per 1 sentence. On the other hand, the percentage of grammar mistakes is almost $38 \%$ (see table 1), which, as compared to the previously shown ratio, is rather a positive result. However, grammar has been reported as the most problematic aspect of the written composition in general. In addition, the proportion between the total number of words and the number of grammar mistakes is 14.6 , so it shows that a mistake in grammar has been found in more than every 14th word (Kaczmarczyk 48-52, 66-67). As far as the answer to Q2.3 is concerned, the results show that only 1 of the subjects has used 1 transition signal (Kaczmarczyk 51).

To comment on Q2.4, one should remember that the ratio between the total number of words and the number of inadequate words is 17.04. It shows that more than every 17 th word is inaccurate. Additionally, the percentage between these two aspects is $5.87 \%$ (Kaczmarczyk 51-52). Analyzing the results further, it has been observed that the proportion between the number of inadequate words and the spelling mistakes is 1.94 and one can see that almost every 2 nd inadequate word is spelt incorrectly. To analyze the phenomenon of the inadequacy of vocabulary, let us focus on the fact that vocabulary causes the most problems (Kaczmarczyk $52-53,66-67)$.

In Q2.5 the ratio of total vocabulary used to the number of spelling mistakes shows that more than every 33rd word contained a spelling error. To link the previous question (about the inadequate vocabulary) and the mistakes in spelling, the percentage between the number of the latter (78) and the number of inadequate words with no spelling mistakes (74) is $51.3 \%$. On the other hand, the spelling mistakes appeared to be more problematic (Kaczmarczyk 65-67).

To comment on Q3, the results show that the students did not have major problems with the appropriate number of words for the composition. What tends to be interesting is that the gap between the composition with the highest number of words (109) and the composition with the lowest number of words (48) 
is 61 words. Furthermore, only 4 written compositions contained more than 100 words and only 1 contained less than 50 words. Comparing the results, one can assume that the students tend to use more words than required in a written composition (4 to 1) (Kaczmarczyk 57-58).

Apart from the research questions, some additional pieces of information have been observed and analyzed. First of all, there is the ratio and the percentage between the number of words and the number of sentences, which is 10.6 and $9.42 \%$, respectively. It gives the number of 11 words per sentence (Kaczmarczyk 58-59). Furthermore, the highest ratio between the number of words and the number of sentences is 21 . On the other hand, the lowest ratio between the two aspects is 6.538 . The gap between them is approximately 14.46. In terms of the average number of words per sentence, the results show that the most frequent number is 10 . On the contrary, the average numbers of $6,14,15,17,18$ and 21 words for one sentence appear only once each (Kaczmarczyk 59-63).

Table 2: Mistakes according to their types. Based on Kaczmarczyk (64-68)

\begin{tabular}{|l|c|}
\hline All mistakes & 471 \\
\hline Grammar & 177 \\
\hline Inadequate vocabulary & 152 \\
\hline Spelling & 78 \\
\hline Punctuation & 41 \\
\hline Text organization & 23 \\
\hline
\end{tabular}

\section{Discussion of the results}

After a presentation of the results, let us offer their interpretation. As it has been seen, the most problematic areas for the research group were grammar $(37.6 \%$ of mistakes) and vocabulary problems (32.27\%). Moreover, spelling mistakes constituted $16.6 \%$ of all mistakes. Only one transition signal was used. Only 7 students met all of the task requirements (6 per composition), however, more than one third of the group $(30.3 \%)$ wrote compositions without any mistake. The vast majority of students had an appropriate number of words per written composition. The students had no major problems with punctuation (only $8.7 \%$ ) and text organization $(4.88 \%)$.

The subjects of the research group, as typical Polish students of English as a foreign language (English in Poland), showed difficulties in facing differences between languages such as difference between pronunciation and spelling in English or tense aspects different than in the Polish language. Hence, the number of mistakes in grammar or spelling is not surprising. Insufficient vocabulary 
or practically the lack of use of transition signals may be due to the little time allocated to studying. However, finding the source of problems was not the aim of the research. Meeting the requirements for the written composition (mention three aspects and develop them) was also more problematic. On the other hand, the subjects presented some level of mastery in the rules of punctuation and text organization. Also, the majority of subjects had the appropriate number of words per written composition.

All in all, the research group showed more problematic areas than unproblematic ones. The subjects succeeded in three aspects (out of eight), namely appropriate word number, punctuation and text organization. The aspect of sentence number was needed to see the word count in an average sentence. This constitutes $37.5 \%$ of the success in all aspects.

\section{Conclusions and teaching implications}

In terms of conclusions, the results show that the students did not have major problems with text organization or punctuation rules, which is satisfactory. Additionally, the average length of the written composition fits into the standards (the student should write between 50 and 100 words). Only five compositions did not have an adequate number of words (Kaczmarczyk 45-47, 57).

On the other hand, however, the results for the rest of the aspects show that the subjects had some problems with grammar, spelling and inadequacy of vocabulary. Moreover, only one student used one transition signal. What is problematic as well is the accomplishment of the task requirements (six requirements for a written composition). The study has shown that there were only seven cases in which all of the requirements were met (Kaczmarczyk 44-65).

The results showed some weak points of students in the written task. For future research, what may be worth examining is the study of more written compositions, which should be conducted at the same level of proficiency. However, the studies of the writing skill in both primary school students and high school students should also be implemented.

As for the teaching implications, in terms of the aspects that were analyzed, what should be practiced more in the future is grammar, vocabulary, transition signals and meeting the requirements. However, aspects such as punctuation, text organization rules and practicing the appropriate number of words per written composition should not be neglected, although the subjects had no major problems with them (Kaczmarczyk 68). 


\section{References}

Brown, D. H. 2014. Principles of Language Learning and Teaching: A Course in Second Language Acquisition. 6th ed. White Plains: Pearson Education.

CKE. 2010. Informator o egzaminie gimnazjalnym od roku szkolnego 2011/2012. Warszawa: Centralna Komisja Egzaminacyjna. Retrieved from https://www.cke.edu.pl/images/stories/0012 Gimnazjum/100826_Informator\%20gimnazjalny.pdf. 31 Dec. 2016.

—. 2015a. Osiagnięcia uczniów kończacych gimnazjum w roku 2015. Warszawa: Centralna Komisja Egzaminacyjna. Retrieved from https://www.cke.edu.pl/images/_EGZAMIN_GIMNAZJALNY/ Informacje_o_wynikach/Sprawozdanie_z_egzaminu_gimnazjalnego_2015.pdf. 26 Mar. 2016.

-. 2015b. Sprawozdanie z egzaminu maturalnego 2015, język angielski. Warszawa: Centralna Komisja Egzaminacyjna. Retrieved from https://www.cke.edu.pl/images/_EGZAMIN_ MATURALNY OD 2015/Informacje_o wynikach/2015/sprawozdanie/raport_2015 angielski_c.pdf. 26 Mar. 2016.

—. 2016a. Osiagnięcia uczniów kończacych gimnazjum w roku 2016. Retrieved from https://www. cke.edu.pl/images/_EGZAMIN_GIMNAZJALNY/Informacje_o_wynikach/2016/Sprawozdanie\%20z\%20egzaminu\%20gimnazjalnego_2016.pdf. 26 Mar. 2016.

—.2016b. Sprawozdanie z egzaminu maturalnego 2016, język angielski. Retrieved from https://www. cke.edu.pl/images/_EGZAMIN_MATURALNY_OD_2015/Informacje_o_wynikach/2016/ sprawozdanie/sprawozdanie_matura_2016_angielski.pdf. 26 Mar. 2016.

Council of Europe. 2001. Common European Framework of Reference for Languages: Learning, Teaching, Assessment. Strasbourg: Language Policy Unit. Retrieved from https://www.coe. int/t/dg4/linguistic/Source/Framework_EN.pdf. 1 Oct. 2015.

Dakowska, M. 2007. Teaching English as a Foreign Language: A Guide for Professionals. Warszawa: Państwowe Wydawnictwo Naukowe.

Harmer, J. 2011. The Practice of English Language Teaching. Longman: Pearson Education.

Kaczmarczyk, M. 2017. An Analysis of the Skill of Creating Written Compositions in Junior High School Students. Diss. U of Wrocław.

Lipińska, D. 2014. Polish Learners Attitudes towards Learning English Pronunciation: Revised. Łódź: U of Łódź. Retrieved from http://dspace.uni.lodz.pl:8080/xmlui/bitstream/ handle/11089/14009/8-129_149-Lipi\%C5\%84ska.pdf?sequence=1\&isAllowed=y. 30 Mar. 2017.

MEN. 2009. Podstawa programowa z komentarzami: Tom 3. Języki obce w szkole podstawowej, gimnazjum i liceum. Warszawa: Ministerstwo Edukacji Narodowej.

Pawlak, M. 2006. The Place of Form-Focused Instruction in the Foreign Language Classroom. Kalisz: Wydział Pedagogiczno-Artystyczny w Kaliszu UAM w Poznaniu.

Saville-Troike, M. 2007. Introducing Second Language Acquisition. Cambridge: Cambridge UP. Ur, P. 2012. A Course in English Language Teaching. Cambridge: Cambridge UP.

Weigle, S. C. 2009. Assessing Writing. Cambridge: Cambridge UP.

Zając, M. 2015. Phonetic Convergence in the Speech of Polish learners of English. Łódź: U of Łódź. Retrieved from http://dspace.uni.lodz.pl:8080/xmlui/bitstream/handle/11089/8938/Zaj\%C4\%85c\%20 -\%20PhD $\% 20$ dissertation $\% 20-\% 20$ Phonetic $\% 20$ convergence $\% 20$ in $\% 20$ the $\% 20$ speech $\% 20$ of $\% 20$ Polish $\% 20$ learners\%20of\%20English.pdf?sequence=1\&isAllowed=y. 30 Mar. 2017. 


\section{Appendix}

In the latter part of the article, an example of an analysis sheet has been shown.

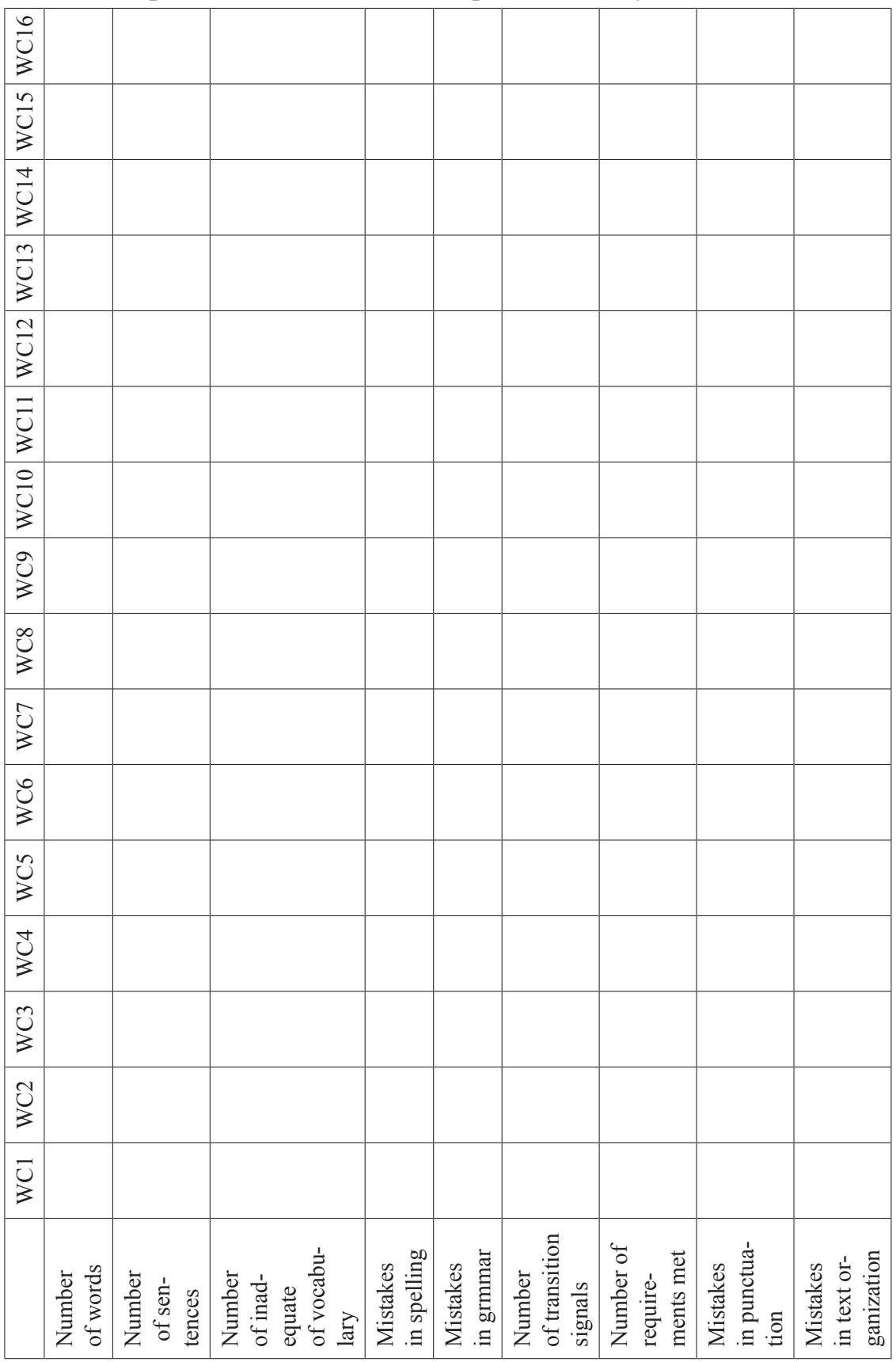

Figure 1: An example of an analysis sheet. Based on Kaczmarczyk (77) 